\title{
Uji Aktivitas Antibakteri Ekstrak Metanol Daun Kecubung (Datura metel L.) TERHADAP Bakteri Streptococcus pneumonia dan Klabsiella pneumonia
}

\author{
A. Mu'thi Andy Suryadi', Moh. Adam Mustapa ${ }^{2}$, Faramita Hiola ${ }^{3}$, Sintiya Basiru ${ }^{*}$ \\ 1,2,3,4 Jurusan Farmasi, Fakultas Olahraga dan Kesehatan, Universitas Negeri Gorontalo, Gorontalo \\ ${ }^{*}$ E-mail: sintiyabasiru4@gmail.com
}

\section{Article Info:}

Received: 10 Juli 2021

in revised form: 18 Juli 2021

Accepted: 29 Agustus 2021

Available Online: 29 Agustus 2021

\begin{tabular}{l} 
Keywords: \\
Identification \\
Characteritation \\
Alkaloid \\
Datura metel L. \\
\hline Corresponding Author: \\
Sintiya Basiru \\
Jurusan Farmasi \\
Fakultas Olahraga dan \\
Kesehatan \\
Universitas Negeri Gorontalo \\
E-mail: sintiyabasiru4@gmail.com
\end{tabular}

\begin{abstract}
Infectious disease is a disease caused by microbes, including bacteria. One of the microorganisms that often causes infectious disease is Streptococcus pneumoniae and Klabsiella pneumoniae. Based on empirical data, plant that has antimicrobial potential is amethyst leaves (Datura metel L.). This study aims to know the antibacterial activity and concertration of amethyst leaves (Datura metel L.) against Streptococcus pneumoniae and Klabsiella pneumonia. This is an experimental study which includes antibacterial activity test, MIC (Minimum Inhibitor Concertration) test, MFC (Minimum Fungicidal Concertration) test, and bacterial potency test. The finding shows that the antibacterial activity test of amethyst leaves (Datura metel L.) methanol extract is able to inhibit bacterial growth of Streptococcus pneumonia at a minimum inhibitor concertration of $15 \%$ and an optimum concertration of $50 \%$ with an average of 16.33 $\mathrm{mm}$ and $19.30 \mathrm{~mm}$. Meanwhile, for Klabsiella pneumoniae, the minimum inhibitor concertration is $20 \%$ and the optimum concertration is $50 \%$, with an average of $13.82 \mathrm{~mm}$ and $17.73 \mathrm{~mm}$. this is based on the results of One Way Anova data $(a<0.01)$ with a $99 \%$ confidance level.
\end{abstract}

Copyright $(2021$ IJPE-UNG

This open access article is distributed under a Creative Commons Attribution (CC-BY-NC-SA) 4.0 International license.

How to cite (APA $6^{\text {th }}$ Style):

Suryadi.A.M.A Mustapa.M.A.,Hiola.F.,Basiru.S.(2021). Uji Aktivitas Antibakteri Ekstrak Metanol Daun Kecubung (Datura metel L.) Terhadap Bakteri Streptococcus pneumonia Dan Klabsiella Indonesian Journal of Pharmaceutical (e-Journal),1(3), 179-189. 


\section{ABSTRAK}

Penyakit infeksi merupakan salah satu penyakit yang disebabkan oleh mikroba diantaranya bakteri. Salah satu mikroorgansime yang sering menyebabkan penyakit infeksi yakni Streptococcus pneumonia dan Klabsiella pneumonia. Berdasarkan data empiris, tanaman yang memiliki potensi antimikroba yaitu daun kecubung (Datura metel L.). Penelitian ini bertujuan untuk mengetahui aktivitas dan konsentrasi antibakteri daun kecubung (Datura metel L.) terhadap Streptococcus pneumonia dan Klabsiella pneumonia. Penelitian ini merupakan penelitian eksperimental yang meliputi, uji aktivitas antibakteri, uji KHM, uji KBM dan uji potensi antibakteri. Hasil penelitian uji aktivitas antibakteri ekstrak metanol daun kecubung (Datura metel L.) mampu menghambat pertumbuhan bakteri Streptococcus pneumonia pada kosentrasi hambat minimum $15 \%$ dan kosentrasi optimum $50 \%$ dengan rata-rata $16,33 \mathrm{~mm}$ dan $19,30 \mathrm{~mm}$ sedangkan Klabsiella pneumonia kosentrasi hambat minimum 20\% dan kosentrasi optimum $50 \%$ dengan rata-rata 13,82 $\mathrm{mm}$ dan rata-rata $17,73 \mathrm{~mm}$. Hasil data One Way Anova $(\alpha<0,01)$ dengan tingkat kepercayaan $99 \%$.

Kata Kunci: Kecubung, S.pneumonia, K.pneumonia, Antibakteri

\section{Pendahuluan}

Infeksi ialah penyakit yang dapat ditularkan dari satu orang keorang lain atau dari hewan kemanusia. Infeksi ini dapat disebabkan oleh masuk dan berkembang biaknya mikroorganisme seperti bakteri, virus, jamur, prion dan protozoa yang masuk ke dalam tubuh sehingga menyebabkan kerusakan organ [4]. Salah satu mikrorganisme yang dapat menyebabkan kematian tertinggi didunia yakni bakteri Streptococcus pneumonia dan Klabsiella pneumonia [15]. oleh karena itu pemberian antibakteri merupakan salah satu pilihan yang sangat penting dalam menangani penyakit infeksi yang disebabkan oleh bakteri.

Pemberian antibakteri yang tidak terkontrol menimbulkan masalah dalam pengobatan penyakit infeksi yakni dapat mendorong terjadinya perkembangan resistensi terhadap antibakteri yang diberikan. Resistensi terhadap bakteri yang utamanya peka dalam bahan antibakterial, diakibatkan adanya mutase kromosom maupun pergantian material genetic terhadap mikroorganisme [7]. Resistensi bakterial ditinjau dari segi biokimiawi bisa terbentuk melewati mekanisme penurunan permeabilitasan bakterial bagi obat, inaktivasi antimikroba oleh enzim yang diperoleh melalui bakteri, memperbaiki reseptor obat, serta peningkatan sintesa zat yang sifatnya antagonis pada obat [9]. Sehingga diperlukan usaha dalam mengembangkan obat tradisional berbahan herbal yang dapat membunuh bakteri untuk menghindari terjadinya resistensi tersebut.

Salah satu tanaman yang secara empiris digunakan oleh masyarakat sebagai bahan obat yaitu kecubung. Salah satu bagian yang berkhasiat sebagai obat pada tanaman ini yaitu daun, yakni digunakan sebagai antibakteri, antiinflamasi. Efek ini muncul karena diakibatkan adanya kedudukan zat fitokimia misalnya alkaloid, flavonoid, saponin, serta tanin yang dapat bekerja untuk berbagai jenis penyakit [1].

Kecubung (Datura metel L.) kerap dikenal sebagai salah satu tanaman berefek negatif yakni efeknya yang bersifat membius, mabuk atau racun akibat penggunaan yang berlebihan Meskipun begitu tanaman kecubung di masyarakat pedesaan digunakan sebagai obat asma, dilakukan dengan cara membakar sedikit bagian ujung lintingan daun atau bunga kecubung lalu menghirup asap yang dihasilkan dari proses pembakaran daun atau bunga tanaman kecubung.

Sesuai dengan deskripsi tersebut serta pemakaian empiris dengan cara meluas perawatan warga pedesaan memakai daun kecubung juga tidak terdapat informasi ilmiah mengenai percobaan aktivitasan antibakteri tumbuhan tersebut pada Indonesia, sehingga peneliti tertarik melakukan pengamatan mengenai aktivitasan antibakterial ekstrak metanol daun kecubung (Datura metel L.) terhadap bakteri Streptococcus pneumonia dan Klabsiella pneumonia. 


\section{Metode Penelitian}

Alat Dan Bahan

Alat yang digunakan pada penelitian kali ini adalah Api bunsen, Autoklaf, Batang pengaduk, Cawan petri,Gelas kimia $100 \mathrm{ml}$ (Pyrex IWAKI), Gelas ukur $10 \mathrm{ml}$, Gelas ukur $100 \mathrm{ml}$ (Pyrex IWAKI), Inkubator, Jarum ose,Kamera digital, Lemari pendingin (kulkas), Mistar, Neraca analitik, Oven, Penangas air, Pinset, Pipet mikro, Rak tabung reaksi, Tabung reaksi, Timbangan digital, Vacummrotary evaporator, Wadah maserasi.

Bahan yang digunakan pada penelitian ini adalah tanaman kecubung (Datura metelL.) yang diperoleh dari kabupaten Gorontalo desa dulamayo, Media NutrientAgar (NA), Media Nutrient Broth (NB), Reagen mayer, Pereaksi Lieberman-burchard, Pereaksi dragendroff,Metanol,Bakteri Streptococcus pneumonia dan Klabsiella pneumonia, Cakram kertas, Kertas saring, Korek api,Kloramfenikol, Tissue, Spritus, Kapas, Aquades.

Prosedur Penelitian

Pembuatan Simplisia

Daun kecubung (Datura metel L.) dikumpulkan terlebih dahulu, setelah dikumpulkan dilakukan sortasi basah dimana tujuannya untuk memisahkan kotoran-kotoran atau bahanbahan asing lainnya. Kemudian daun kecubung dicuci untuk menghilangkan tanah atau pengotor lainnya yang melekat pada sampel, lalu dicuci dengan menggunakan air mengalir. kemudian dilakukan perajangan untuk mempermudah proses pengeringan, pengepakan serta penggilingan. Pengeringan dilakukan dengan cara diangin-anginkan diudara yang terbuka terlindung dari sinar matahari dimana tujuannya untuk menghilangkan kadar air hingga didapat berat kosntan. Sampel diserbuk menggunakan bleander dan kemudian ditimbang berat sampel.

Pembuatan Ekstrak

Pembuatan ekstrak ini dilakukan dilaboratorium Fitokimia Farmasi di Universitas Negeri Gorontalo. Pada proses sampel di ekstrak dengan menggunakan metode maserasi dengan cara merendam sampel menggunakan pelarut metanol selama $1 \times 24$ jam.

Sebelum melakukan proses ekstraksi yang dilakukan terlebih dahulu yakni menimbang sampel daun kecubung sebanyak 150 gr, kemudian sampel daun kecubung direndam dengan menggunakan pelarut metanol sebanyak 2 liter yang ditempatkan di dalam toples kaca, usahakan sampel tersebut terendam sempurna kemudian diaduk menggunakan magnetic stirer. Setelah itu sampel didiamkan selama 24 jam dan dengan sesekali diaduk. Kemudian sampel disaring menggunakan kain saring sampai mendapatkan ekstrak cair. Residu yang tertinggal direndam dengan pelarut yang sama dalam waktu $1 \times 24$ jam dan filtrat di saring. Rotary evvaporator digunakan untuk memekatkan hasil filtrat yang sudah di dapatkan hingga memperoleh ekstrak metanol kental [11].

Skrining Fitokimia

Dilakukan pengujian skrining fitokimia ekstrak metanol daun kecubung (Datura metel L.) meliputi uji Alkaloid, Flavonoid, Saponin, Tanin dan Steroid [6].

Persiapan Uji Aktivitas Antibakteri

Persiapan uji akitivtas antibakteri meliputi sterilisasi alat, pembuatan media nutrien agar (NA) dengan melarutkan media NA bersama aquades hingga tercampur homogen, kemudian dimasukkan kedalam erlenmeyer disumbat menggunakan kapas, kemudian disterilkan dengan autoklaf [2], pembuatan media nutrien broth (NB), pembuatan Mc.Farland 0,5\% setelah itu dibandingkan suspensi bakteri dengan standar kekeruhan dilihat dengan menggunakan latar belakang kertas putih, apabila suspensi kurang keruh maka ditambahkan koloni dan apabila lebih keruh perlu ditambahkan dengan $\mathrm{NaCI}$ 0,9\% [10]. Kekeruhan suspensi mikroba uji diukur dengan alat spektrofotometer UV-Vis dengan panjang gelombang $580 \mathrm{~nm}$ dengan transmitan $25 \%$ [3]. inokulasi bakteri uji digors pada permukaan agar menggunakan jarum ose steril untuk melakukan peremajaan, kemudian diinkubasi dalam kondisi anaerob selamam 24 jam [8].pembuatan suspensi bakteri, pembuatan larutan uji, pembuatan larutan kontrol. Tahap awal pengujian yaitu uji skrining antimikroba pada ekstrak metanol daun kecubung menggunakan metode Streak Plate (gores). Hal pertama yang dilakukan yaitu masing-masing ekstrak dicampur 
bersamaan dengan DMSO, lalu diaduk hingga larut. Setelah larut, ditambahkan media nutrien agar yang telah dicairkan, dicukupkan hingga volume larutan menjadi $10 \mathrm{~mL}$. Kemudian dituang ke dalam cawan petri, dihomogenkan hingga rata dan dibiarkan memadat. Setelah memadat, diambil 1 ose biakan bakteri yang telah disuspensikan dan digoreskan pada media yang telah memadat. Dilakukan hal yang sama untuk kloramfenikol sebagai kontrol positif dan DMSO sebagai kontrol negatif. Kemudian diinkubasi selama $1 \times 24$ jam pada suhu $37^{\circ} \mathrm{C}$. Kemudian diamati hasilnya.

Uji Kadar Hambat Minimum (KHM)

Penentuan kosentrasi hambat minimum dapat dilakukan dengan cara membuat variasi kosentrasi sampel ekstrak daun kecubung yaitu 1\%,5\%,10\%, 15\%, 20\%, 30\%, 40\%, dan 50\%. Pada uji ini digunakan metode dilusi cair dengan cara menyiapkan beberapa tabung reaksi yang sudah disterilkan terlebih dulu, untuk kontrol negatif digunakan larutan DMSO dan untuk larutan kontrol positif digunakan larutan kloramfenikol, kemudian dimasukkan $20 \mu \mathrm{L}$ suspensi bakteri Streptococcus pneumonia dan Klabsiella pneumonia, kemudian ditambahkan sampai $10 \mathrm{ml}$ Nutrient Broth pada masing-masing tabung reaksi, setelah itu larutan uji di vortex. Diinkubasikan pada inkubator dalam temperature $37^{\circ} \mathrm{C}$ hingga $1 \times 24$ jam dan ditinjau kekeruhan, perbandingan menggunakan kontrol positif (Kloramfenikol) dan kontrol negatif (DMSO). Konsentrasi terendah yang tidak menunjukan kejernihan adalah KHM.

Uji Kadar Bunuh Minimum (KBM)

Hasil yang telah didapatkan pada pengujian Konsentrasi Hambat Minimum (KHM), maka selanjutnya dilakukan uji untuk kadar bunuh minimum KBM). Disiapkan cawan petri yang berisi media padat nutrient agar (NA) sebagai tempat kultur bakteri. Selanjutnya dilakukan penggoresan menggunakan jarum ose steril pada masing-masing kosentrasi hasil dari kadar hambat minimum di atas permukaan media padat. Kemudian media kultur diinkubasi selama 1 x 24 jam pada suhu $37^{\circ} \mathrm{C}$. Diamati kadar bunuh minimum dengan ada tidaknya pertumbuhan koloni bakteri diatas permukaan media padat itulah hasil dari Kadar Bunuh Minimal (KBM).

Uji Potensi Antibakteri

Pengujian aktivitas antibakteri dilakukan denganmenggunakan metode difusi cakram dan dilusi cair. Tahapan pertama yaitu kertas cakram yang berdiameter $0,5 \mathrm{~cm}$ diambilkan dengan cara aseptis memakai pinset yang sudah disterilisasikan. Kertas cakram tercelupkan kedalam masing-masing konsentrasi ekstrak daun kecubung selama \pm 30 menit sampai 1 jam, setelah itu diletakkan diatas permukaan media yang berisi bakteri uji, kontrol negatif yang digunakan DMSO 10\% dan Kloramfenikol sebagai kontrol positif. Perlakuan ini dilakukan sebanyak 3 kali. Media yang telah diberi perlakuan diinkubasi selama 48 jam pada suhu $37^{\circ} \mathrm{C}$. Aktivitas antibakteri ekstrak daun kecubung dilihat berdasarkan zona hambatan yang diperoleh. Zona hambatan ditinjau sangat bening dibanding kawasan sekeklilingnya serta belum dihidupi bakteri. Zona hambatannya terukur memakai jangka sorong melalui batasan terluar kertas saring hingga batasan terpanjang serta batasan terpendek kawasan hambatan yang dibentuk sampai bisa didapatkan jari-jari zona hambatan terpanjang serta jari-jari zona hambatan terpendek.

Analisis Data

Untuk mengetahui perbedaan yang bermakna dari uji potensi pada ekstrak metanol daun kecubung (Datura metel L.) sebagai antimikroba digunakan One Way ANOVA pada $\alpha=$ 0,01, dengan taraf kepercayaan $99 \%$.

3. Hasil dan Pembahasan

Rendamen Ekstrak

Berdasarkan hasil rendamen ekstrak (Tabel 1) menunjukkan hasil \% rendamen dari ekstrak daun kecubung, dimana ekstrak daun kecubung dengan berat sampel sebelumnya yaitu 150 gram diekstraksi dengan menggunakan pelarut metanol sebanyak 2 liter menghasilkan ekstrak kental daun kecubung sebanyak 20 gram dengan persen rendamen 13,33 $\%$. 
Tabel 1. Hasil Rendamen Ekstrak

\begin{tabular}{cccc}
\hline Berat Sampel & Metanol (L) & Berat Ekstrak (gr) & Rendamen (\%) \\
\hline 150 gram & 2 liter & 20 gram & $13,33 \%$ \\
\hline
\end{tabular}

Hal ini menunjukkan bahwa proses ekstraksi mengugunakan pelarut metanol daun kecubung (Datura metel L.) berlangsung baik. Persentase rendamen dapat dikatakan sempurna jika hasilnya berkisar anatra $10-15 \%$ [5].

Uji Penapisan Fitokimia

Pada uji penapisan fitokimia ekstrak metanol daun kecubung (Datura metel L.) dengan menggunakan metode kualitatif uji warna didapatkan hasil positif alkaloid yang ditandai dengan adanya endapan merah jingga. Senyawa flavonoid yang ditandai dengan warna jingga, senyawa saponin yang ditandai dengan timbulnya busa setinggi $1 \mathrm{~cm}$, senyawa tanin hijau kehitaman dan senyawa steroid ditandai dengan warna hijau kebiruan.

Tabel.2 Hasil Uji Penapisan Fitokimia

\begin{tabular}{cccc}
\hline Senyawa & Pereaksi & Hasil & Keterangan \\
\hline Alkaloid & $\begin{array}{c}\text { HCL }+ \text { pereaksi } \\
\text { Liberman } \\
\text { Bourchard }\end{array}$ & $\begin{array}{c}\text { Endapan } \\
\text { berwarna coklat } \\
\text { sampai hitam }\end{array}$ & Positif Alkaloid \\
\hline Flavonoid & $\begin{array}{c}\text { Serbuk magnesium } \\
+ \text { HCL + etanol }\end{array}$ & $\begin{array}{c}\text { Jingga } \\
\text { kemerahan }\end{array}$ & Positif Flavonoid \\
\hline Saponin & Aquadest & Berbusa & Positif Saponin \\
\hline Steroid/Triterpen & $\begin{array}{c}\text { Kloroform + asam } \\
\text { Asetat Anhidrat }+ \\
\text { Asam Sulfat pekat }\end{array}$ & Hijau kebiruan & $\begin{array}{c}\text { Positif } \\
\text { Steroid }\end{array}$ \\
\hline Tanin & FeCL & Hijau kehitaman & Positif Tanin \\
\hline
\end{tabular}

Uji Aktivitas Antibakteri

Hasil penelitian menunjukkan bahwa, pada media NA yang mengandung ekstrak metanol daun kecubung tidak terdapat pertumbuhan bakteri Streptococcus pneumonia dan Klabsiella pneumonia.

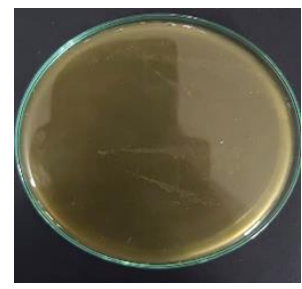

Gambar 1 : Pertumbuhan bakteri Ekstrak Metanol Daun kecubung terhadap bakteri Streptococcus pneumonia

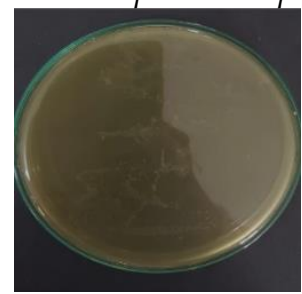

Gambar 2 : Pertumbuhan bakteri Ekstrak Metanol Daun Kecubung terhadap bakteri Klabsiella pneumonia 


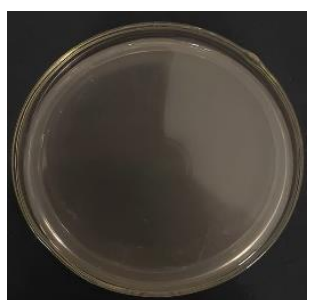

Gambar 3 : Pertumbuhan bakteri Streptococcus pneumonia pada kontrol positif (kloramfenikol)

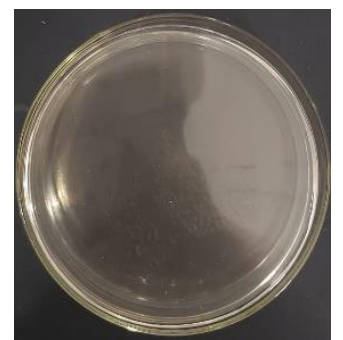

Gambar 4 : Pertumbuhan bakteri Klabsiella pneumonia pada kontrol positif (Kloramfenikol)

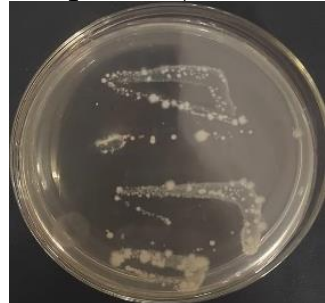

Gambar 5 : Pertumbuhan bakteri Streptococcus pneumonia pada kontrol negatif (DMSO)

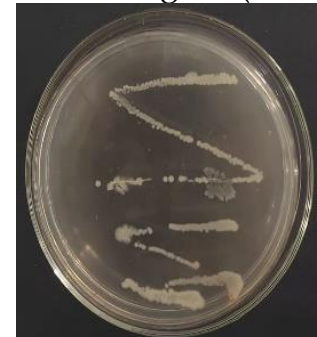

Gambar 6 : Pertumbuhan bakteri Klabsiella pneumonia pada kontrol negatif (DMSO)

Uji Kadar Hambat Minimum

Tabel 3. Hasil Uji KHM

\begin{tabular}{|c|c|c|c|c|}
\hline Ekstrak & Bakteri & Kosentrasi & Aktivitas & Keterangan \\
\hline & Streptococcus & $0,1 \%$ & Keruh & Tidak menghambat \\
\hline & pneumonia & $1 \%$ & Keruh & Tidak menghambat \\
\hline & & $5 \%$ & Keruh & Tidak menghambat \\
\hline & & $10 \%$ & Tidak keruh & Menghambat \\
\hline & & $15 \%$ & Tidak keruh & Menghambat \\
\hline & & $20 \%$ & Tidak keruh & Menghambat \\
\hline & & $30 \%$ & Tidak keruh & Menghambat \\
\hline
\end{tabular}




\begin{tabular}{|c|c|c|c|c|}
\hline & & $40 \%$ & Tidak keruh & Menghambat \\
\hline Daun & & $50 \%$ & Tidak keruh & Menghambat \\
\hline kecubung & Klabsiella & $0,1 \%$ & Keruh & Tidak menghambat \\
\hline (Datura metel & pneumonia & $1 \%$ & Keruh & Tidak menghambat \\
\hline \multirow[t]{7}{*}{ L.) } & & $5 \%$ & Keruh & Tidak menghambat \\
\hline & & $10 \%$ & Keruh & Tidak menghambat \\
\hline & & $15 \%$ & Tidak keruh & Menghambat \\
\hline & & $20 \%$ & Tidak keruh & Menghambat \\
\hline & & $30 \%$ & Tidak keruh & Menghambat \\
\hline & & $40 \%$ & Tidak keruh & Menghambat \\
\hline & & $50 \%$ & Tidak keruh & Menghambat \\
\hline
\end{tabular}

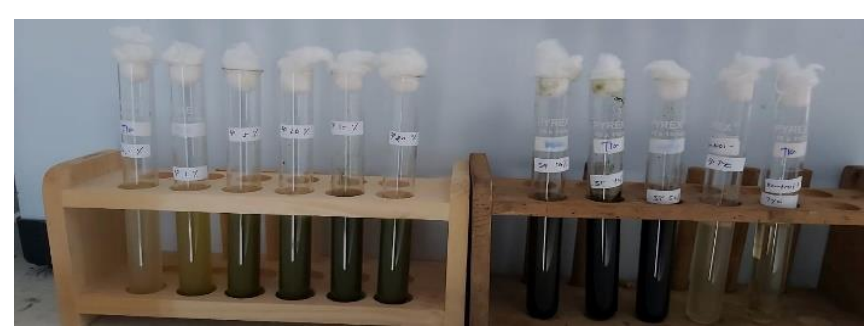

Keterangan :

Konsentrasi 0,1\%, 1\%, 5\%, 10\%, 15\%, 20\%, 30\%, 40\%, 50\%, Kontrol positif dan Kontrol negatif (dilihat dari kiri ke kanan)

\section{Gambar 7. Hasil Uji KHM Streptococcus pneumonia}

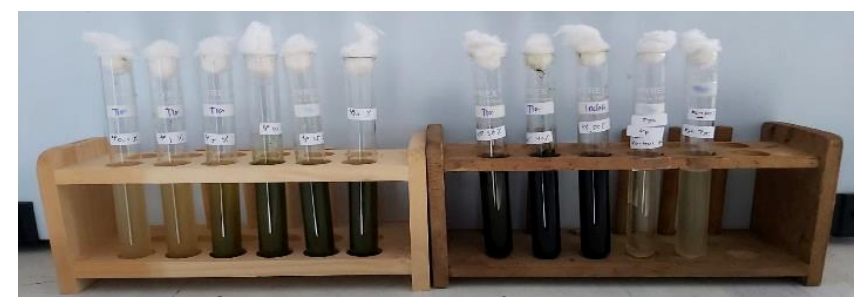

Keterangan :

Konsentrasi 0,1\%, 1\%, 5\%, 10\%, 15\%, 20\%, 30\%, 40\%, 50\%, Kontrol positif dan Kontrol negatif (dilihat dari kiri ke kanan)

Gambar 8. Hasil Uji KHM Klabsiella pneumonia

Kadar hambat minimum (KHM) pada penelitian ini menunjukkan bahwa pada kosentrasi ekstrak daun kecubung (Datura metel L.) 0,1\%, 1\%, 5\% menunjukkan adanya pertumbuhan bakteri Streptococcus pneumonia pada media Nutrient Broth, sedangkan pada kosentrasi 10\%, 15\%, 20\%, 30\%, 40\% 50\% tidak menunjukkan adanya pertumbuhan bakteri Streptococcus pneumonia pada media Nutrient Broth. Selanjutnya untuk hasil kosentrasi ekstrak daun kecubung (Datura metel L.) 0,1\%, 1\%, 5\%, 10\% menunjukkan adanya pertumbuhan bakteri Klabsiella pneumonia pada media Nutrient Broth, sedangkan pada kosentrasi 15\%, 20\%, 30\%, 40\% $50 \%$ tidak menunjukkan pertumbuhan bakteri Klabsiella pneumonia pada media Nutrient Broth. Aktivitas Antibakteri dibagi menjadi 4 yakni, aktivitas sangat kuat jika nilai kadar hambat minimum kurang dari $100 \mu \mathrm{g} / \mathrm{ml}$, aktivitas antibakteri cukup kuat apabila nilai kadar hambat $100-500 \mu \mathrm{g} / \mathrm{ml}$, aktivitas antibakteri lemah jika kadar hambat minimum 500-1000 $\mu \mathrm{g} / \mathrm{ml}$ [8]. 
Uji Kadar Bunuh Minimum

Tabel 4. Hasil Uji KBM

\begin{tabular}{|c|c|c|c|c|}
\hline Ekstrak & Bakteri & Kosentrasi & Aktivitas & Keterangan \\
\hline \multirow{18}{*}{$\begin{array}{c}\text { Daun } \\
\text { kecubung } \\
\text { (Datura metel } \\
\text { L.) }\end{array}$} & Streptococcus & $0,1 \%$ & Tumbuh & Tidak membunuh \\
\hline & pneumonia & $1 \%$ & Tumbuh & Tidak membunuh \\
\hline & & $5 \%$ & Tumbuh & Tidak membunuh \\
\hline & & $10 \%$ & Tumbuh & Tidak membunuh \\
\hline & & $15 \%$ & Tidak tumbuh & Membunuh \\
\hline & & $20 \%$ & Tidak tumbuh & Membunuh \\
\hline & & $30 \%$ & Tidak tumbuh & Membunuh \\
\hline & & $40 \%$ & Tidak tumbuh & Membunuh \\
\hline & & $50 \%$ & Tidak tumbuh & Membunuh \\
\hline & Klabsiella & $0,1 \%$ & Tumbuh & Tidak membunuh \\
\hline & pneumonia & $1 \%$ & Tumbuh & Tidak membunuh \\
\hline & & $5 \%$ & Tumbuh & Tidak membunuh \\
\hline & & $10 \%$ & Tumbuh & Tidak membunuh \\
\hline & & $15 \%$ & Tumbuh & Tidak membunuh \\
\hline & & $20 \%$ & Tidak tumbuh & Membunuh \\
\hline & & $30 \%$ & Tidak tumbuh & Membunuh \\
\hline & & $40 \%$ & Tidak tumbuh & Membunuh \\
\hline & & $50 \%$ & Tidak tumbuh & Membunuh \\
\hline & $0,1 \%$ & & & + \\
\hline
\end{tabular}

Gambar 9. Hasil uji KBM Streptococcus pneumonia
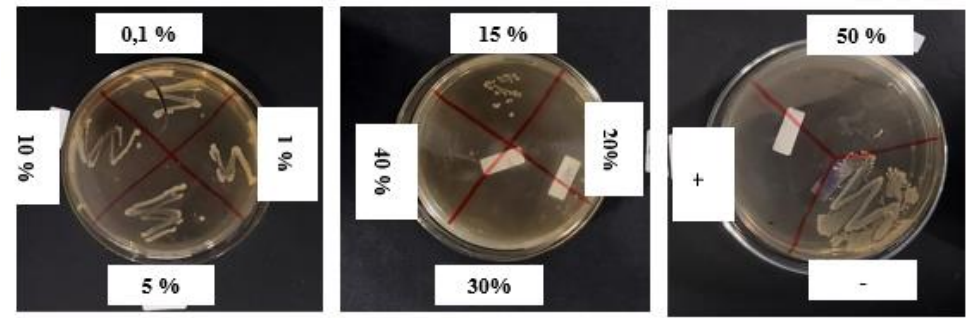

Gambar 10. Hasil uji KBM Klabsiella pneumonia

Kadar Bunuh Minimum (KBM) ekstrak daun kecubung (Datura metel L.) pada kosentrasi 0,1\%, 1\%,5\%,10\% menunjukkan adanya pertumbuhan bakteri Streptococcus pneumonia pada media Nutrient Agar, sedangkan pada kosentrasi 15\%, 20\%, 30\%,40\% 50\% tidak menunjukkan adanya pertumbuhan bakteri Streptococcus pneumonia pada media Nutrient Agar. 
Kadar Bunuh Minimum (KBM) ekstrak daun kecubung (Datura metel L.) pada konsentrasi $0,1 \%, 1 \%, 5 \%, 10 \%, 15 \%$ menunjukkan adanya pertumbuhan bakteri Klabsiella pneumonia pada media Nutrient Agar, sedangkan pada kosentrasi 20\%, 30\%, 40\% 50\% tidak menunjukkan pertumbuhan bakteri Klabsiella pneumonia pada media Nutrient Agar.

Kemampaun ekstrak metanol daun kecubung (Datura metel L.) dalam menghambat bakteri diduga karena adanya kandungan senyawa golongan flavonoid, saponin, tanin, alkaloid, dan steroid yang memiliki aktivitas sebagai antibakteri pada ekstrak tersebut. Adanya senyawa alkaloid menunjukkan bahwa ekstrak metanol daun kecubung (Datura metel L.) memiliki aktivitas antibakteri [12].

Uji Potensi Antibakteri

Tabel 5. Hasil Uji Potensi Antibakteri Ekstrak Daun Kecubung terhadap bakteri Streptococcus pneumonia

\begin{tabular}{|c|c|c|c|c|c|c|}
\hline \multirow[t]{3}{*}{ No } & \multirow[t]{3}{*}{ Perlakuan } & \multirow{2}{*}{\multicolumn{3}{|c|}{$\begin{array}{c}\text { Diameter Zona } \\
\text { Hambatan (mm) } \\
\text { Replikasi }\end{array}$}} & \multirow[t]{3}{*}{$\begin{array}{c}\text { Rata-Rata } \\
(\mathrm{mm})\end{array}$} & \multirow[t]{3}{*}{ Ket } \\
\hline & & & & & & \\
\hline & & 1 & 2 & 3 & & \\
\hline 1. & Kontrol Negatif & - & - & - & - & Tidak ada \\
\hline 2. & Kosentrasi 15\% & 16,06 & 16,28 & 16,06 & 16,13 & Kuat \\
\hline 3. & Kosentrasi 20\% & 17,38 & 18,16 & 16,54 & 17,36 & Kuat \\
\hline 4. & Kosentrasi 30\% & 18,21 & 16,82 & 18,45 & 17,82 & Kuat \\
\hline 5. & Kosentrasi 40\% & 17,98 & 19,20 & 19,03 & 18,73 & Kuat \\
\hline 6. & Kosentrasi 50\% & 19,32 & 18,90 & 19,68 & 19,30 & Kuat \\
\hline 7. & Kontrol Positif & 21,67 & 22,20 & 22,45 & 22,15 & Sangat Kuat \\
\hline
\end{tabular}

Tabel 6. Hasil Uji Potensi Antibakteri Ekstrak Daun Kecubung terhadap bakteri Klabsiella pneumonia

\begin{tabular}{|c|c|c|c|c|c|c|}
\hline \multirow[t]{2}{*}{ No } & \multirow[t]{2}{*}{ Perlakuan } & \multicolumn{3}{|c|}{$\begin{array}{l}\text { Diameter Zona Hambatan } \\
\qquad(\mathrm{mm}) \\
\text { Replikasi }\end{array}$} & \multirow[t]{2}{*}{$\begin{array}{l}\text { Rata-Rata } \\
\qquad(\mathrm{mm})\end{array}$} & \multirow[t]{2}{*}{ Ket } \\
\hline & & 1 & 2 & 3 & & \\
\hline 1. & Kontrol Negatif & - & - & - & - & Tidak ada \\
\hline 2. & Kosentrasi 20\% & 13,09 & 14,17 & 14,22 & 13,82 & Kuat \\
\hline 3. & Kosentrasi 30\% & 13,87 & 14,09 & 14,52 & 14,16 & Kuat \\
\hline 4. & Kosentrasi 40\% & 15,21 & 15,84 & 16,11 & 15,72 & Kuat \\
\hline 5. & Kosentrasi 50\% & 17,46 & 17,52 & 18,22 & 17,73 & Kuat \\
\hline 6. & Kontrol Positif & 21,27 & 21,34 & 22,26 & 21,62 & Sangat kuat \\
\hline
\end{tabular}




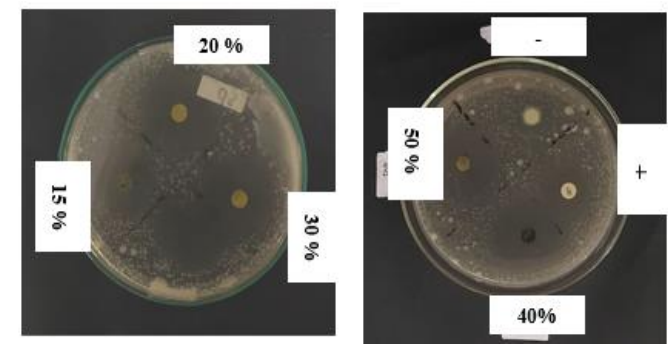

Gambar 11. Daya Hambat Ekstrak Daun Kecubung terhadap Streptococcus pneumonia

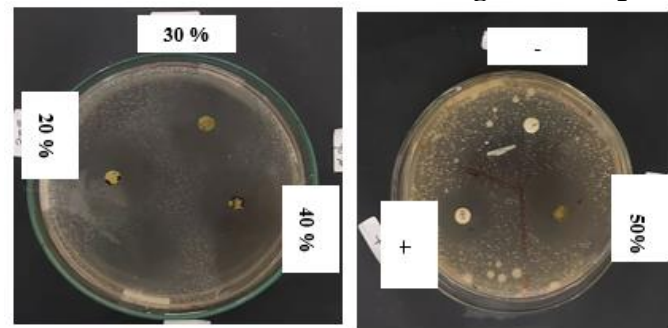

Gambar 12. Daya Hambat Ekstrak Daun Kecubung terhadap Klabsiella pneumonia

Hasil uji zona hambat Ekstrak Daun Kecubung (Datura metel L.) terhadap bakteri Streptococcus pneumonia dapat dilihat pada tabel 5. dimulai pada kosentrasi $15 \%$ dimana zona hambat yang dihasilkan 16,13 mm sampai pada kosentrasi ekstrak 50\% yaitu 19,30 mm, zona hambat yang dihasilkan oleh kontrol positif (kloramfenikol) yaitu rata-rata 22,15 mm dan untuk kontrol negatif (DMSO) yaitu $0 \mathrm{~mm}$ dapat dikatakan tidak memiliki daya hambat.

Hasil uji zona hambat Ekstrak Daun Kecubung (Datura metel L.) terhadap bakteri Klabsiella pneumonia dapat dilihat pada tabel 6. Dimulai pada kosentrasi $20 \%$ dimana zona hambat yang dihasilkan 13,82 mm, sedangkan zona hambat terbesar dihasilkan oleh kosentrasi ekstrak $50 \%$ dengan zona hambat $17,73 \mathrm{~mm}$, zona hambat yang dihasilkan oleh kontrol positif (kloramfenikol) yaitu rata-rata 21,62 mm dan untuk kontrol negatif (DMSO) yaitu $0 \mathrm{~mm}$ dapat dikatakan tidak memiliki daya hambat.

Ketentuan diameter zona hambat bakteri yaitu zona hambat diatas $20 \mathrm{~mm}$ termasuk daya hambat yang sangat kuat, diameter zona hambat 10-20 mm kategori kuat, diameter zona hambat 5-10 kategori sedang, dan diameter zona hambat dibawah 5 termasuk ategori zona hambat lemah [13].

Analisis Data

Berdasarkan hasil analisis statistic, kosentrasi ekstrak daun kecubung (Datura metel L.) berpengaruh terhadap diameter zona hambat pertumbuhan bakteri Streptococcus pneumonia dan Klabsiella pneumonia. Hasil analisis anova, diperoleh nilai signifikan lebih kecil daripada 0,01 $(p<0,01)$ yang berarti terdapat perbedaan yang nyata atau perbedaan secara bermakna terhadap diameter zona hambat $15 \%, 20 \%, 30 \%, 40 \%$ dan 50\%. Dimana konsentrasi 50\% dinilai kuat dalam menghambat pertumbuhan bakteri Streptococcus pneumonia dan Klabsiella pneumonia.

\section{Kesimpulan}

Ekstrak Daun Kecubung (Datura metel L.) memiliki aktivitas dalam menghambat pertumbuhan dari bakteri Streptococcus pneumonia dan Klabsiella pneumonia. Kosentrasi ekstrak daun kecubung (Datura metel L.) dalam menghambat pertumbuhan bakteri Streptococcus pneumonia yaitu pada kosentrasi $15 \%$ sebesar $16,13 \mathrm{~mm}, 20 \%$ sebesar $17,36 \mathrm{~mm}, 30 \%$ sebesar 17,86 $\mathrm{mm}, 40 \%$ sebesar $18,73 \mathrm{~mm}$ dan $50 \%$ sebesar 19,30 mm. Kosentrasi ekstrak daun kecubung (Datura metel L.) dalam menghambat pertumbuhan bakteri Klabsiella pneumonia yaitu pada kosentrasi $20 \%$ sebesar 13,82 $\mathrm{mm}, 30 \%$ sebesar $14,16 \mathrm{~mm}$, 40\% sebesar $15,72 \mathrm{~mm}$ dan $50 \%$ sebesar $17,73 \mathrm{~mm}$. 
Referensi:

[1] Astuti (2009). Sifat Organoleptik Tempe Kedelai yang dibungkus plastic, Daun Pisang, Daun Jati. Karya tulis Ilmiah diterbitkan Universitas Muhammadiyah Surakarta : Surakarta

[2] Aziz. 2010. Metode Penelitian Kesehatan Paradigma Kuantitatif. Health Books Publishing: Surabaya

[3] Cappuccino, James G. 2009. Manual Laboratorium Mikrobiologi. EGC: Jakarta

[4] Darmadi. 2008. Infeksi Nosokomial Problematika dan Pengendaliannya. Jakarta.

[5] Ditjen POM. (2000). Parameter Standar Umum Ekstrak Tumbuhan Obat. Cetakan Pertama. Jakarta: Departemen Kesehatan RI. Halaman 3-5, 10-11.

[6] Harborne, H. 1987. Metode Fitokimia. ITB: Bandung

[7] Herwin dkk. 2018. Aktivitas Antibakteri Ekstrak Etanol Daun Ampas The Hijau (Camellia sinensis L.) terhadap Bakteri Penyebab Jerawat (Propionibacterium acne dan Staphylococcus epidermidis ) Secara Difusi Agar. Makasar: UMI

[8] Holetz, F.B., G. L. Pessini, N.R. Sanchez, D. Aparicio, G. Cortez, C.V. Nakamura, \& B.P.D. Filho. 2002.Screening of Some Plants Used in The Brazillian Folk Medicine for The Treatment of Infectious I.Journal of Bioline.

[9] Jawetz et al., 2001. Mikrobiologi Kedokteran Edisi XXII. Jakarta: Penerbit Salemba Madika

[10] Lamapha, Yulia F. Dan Rupilu Novie S.2008. potensi Lengkuas sebagai Antimikroba (Studi In Vitro pada Bakteri Gram Negatif).

[11] Mould, FL dkk. 2005. In Vitro Microbial Inculum: A Review of its function and properties. Anim Feed Sci Technol. Part 1:31-50. Doi: 10.1016/j.anifeedsci

[12] Mukhriani, 2011. Ekstraksi Pemisahan Senyawa dan Identifikasi Senyawa Aktif, Jurnal Kesehatan

[13] Robinson, T., 1995, Kandungan Organik Tumbuhan Tinggi, Edisi IV. Hal 191-216, Diterjemahkan Oleh Kosasih Padmawinata, ITB., Bandung

[14] Shandar, H.K., B. Kumar, S. Prasher, P. Tiwari, M. Salhan, \& P. Sharma. 2011. A Review Of Phytochemistry And Pharmacology Of Flavonoids. Internationale Pharmaceutica Sciencia, Vol. 1

[15] WHO. Pneumonia : The forgetten killer of children. 2006. Geneva : the United Nations Children's Fund/world Health Organization. 